\title{
Advancing tephrochronology as a global dating tool: applications in volcanology, archaeology, and palaeoclimatic research
}

\author{
Lane, C.S. ${ }^{1 *}$, Lowe, D.J. ${ }^{2}$, Blockley, S.P.E. ${ }^{3}$, Suzuki, T. ${ }^{4}$ and Smith, V.C. ${ }^{5}$ \\ 1. Department of Geography, University of Cambridge, Downing Place, Cambridge, CB2 3EN, United \\ Kingdom \\ 2. School of Science, University of Waikato, Private Bag 3105, Hamilton 3240, New Zealand \\ 3. Centre for Quaternary Research, Royal Holloway University of London, Egham, TW20 OEX, United \\ Kingdom \\ 4. Department of Geography, Tokyo Metropolitan University, Tokyo, 192-0397, Japan \\ 5. Research Laboratory for Archaeology and the History of Art, University of Oxford, Dyson Perrins \\ Building, South Parks Road, Oxford, OX1 3QY, United Kingdom \\ *Corresponding author. \\ E-mail address: csl44@cam.ac.uk (C.S. Lane). \\ Available online 21 April 2017
}

Final pre-publication manuscript April 2017. Definitive version is published at

http://dx.doi.org/10.1016/j.quageo.2017.04.003

Citation:

Lane, C.S., Lowe, D.J., Blockley, S.P.E., Suzuki, T., Smith, V.C. 2017. Advancing tephrochronology as a global dating tool: applications in volcanology, archaeology, and palaeoclimatic research. Quaternary Geochronology 40, 1-7. 


\begin{abstract}
Layers of far-travelled volcanic ash (tephra) from explosive volcanic eruptions provide stratigraphic and numerical dating horizons in sedimentary and volcanic sequences. Such tephra layers may be dispersed over tens to thousands of kilometres from source, reaching far beyond individual volcanic regions. Tephrochronology is consequently a truly global dating tool, with applications increasingly widespread across a range of Quaternary and geoscience disciplines. This special issue of the International Focus Group on Tephrochronology and Volcanism (INTAV) showcases some of the many recent advances in tephrochronology, from methodological developments to diverse applications across volcanological, archaeological, and palaeoclimatological research.
\end{abstract}




\section{Tephrochronology as a global dating tool}

The main value of tephra layers as geochronological units lies in their capacity to act both as dated age markers (tephrochronology) and event-stratigraphic horizons (tephrostratigraphy) for the correlation of widespread sedimentary or volcanic archives. Furthermore, provided that the geochemical and taphonomical integrity of a tephra layer can be demonstrated, there is no maximum age limit to tephrochronology. Few other dating methods are so versatile or robust.

The basis of tephrochronology is the identification of an individual tephra layer and its reliable correlation between deposits found in proximal settings and/or distal sedimentary archives. Ideally, but not always (see Lane et al., 2012), a tephra layer is correlated to a dated individual eruption event. Identification relies upon a combination of physical, mineralogical, or geochemical properties, derived from field and/or laboratory observations or measurements, together with observed stratigraphic and age relationships (e.g. Lowe, 2011; Lowe and Alloway, 2015). Chemical analyses of individual glass shards are especially important for the characterisation of both tephra layers and cryptotephra deposits, especially at distal locations where no other phases (such as minerals) are normally available. The ideal of a unique chemical "fingerprint" for every eruptive has been shown in some cases not to hold (e.g. Lane et al., 2012; Lind et al., 2016). However, this may not prove to be a major limitation where the general chronostratigraphic framework of the tephra is known and can be used to add further constraints on correlation (e.g. Lane et al., 2012). There has recently been a range of new developments in tephra characterisation techniques, such as glass and mineral characterisation methods (e.g. Matsu'ura et al., 2011; Hall and Hayward, 2014; Marcaida et al., 2014; Pearce, 2014; Pearce et al., 2014a; D'Antonio et al., 2016), improved multi-element datasets (e.g. Tomlinson et al., 2015), statistical methods for distinguishing multivariate datasets (e.g. Pouget et al., 2014; Blegen et al., 2015; Bronk Ramsey et al., 2015; Petrelli et al., 2017), new methods for visual assessment of tephra depositional processes and taphonomy (e.g. Griggs et al., 2014, 2015; Hopkins et al., 2015; Zawalna-Geer et al., 2016), and means to extract maximum information from even the finest cryptotephra deposits (e.g. Blockley et al., 2005; Lane et al., 2014; Iverson et al., 2017). These advances now mean that many of the most widespread and/or well-studied tephra or cryptotephra deposits can now be confidently identified and utilised as stratigraphic, and potentially chronological, horizons.

Tephra layers predating historic records may be directly dated by a number of means. In many cases dating is carried out on the mineral or glass components of a deposit, including application of the isothermal-plateau fission-track (ITPFT) dating technique to some of the furthest travelled glass-rich tephra layers (Westgate et al., 2013; Lowe and Alloway, 2015). The most widely applied methods that utilise mineral (crystal) phases include K-Ar and Ar-Ar dating, which typically are undertaken on potassic feldspars, biotite, and hornblende (Deino, 2012; Morgan et al., 2017). However, U-series methods, including $(\mathrm{U} / \mathrm{Th}) / \mathrm{He},{ }^{238} \mathrm{U} /{ }^{230} \mathrm{Th}$, and $\mathrm{U} / \mathrm{Pb}$ for dating primary zircon crystals (Danišík et al., 2012, 2017; Howe et al., 2015; Ito et al., 2017), are growing in use.

Indirect dating of tephra layers, via dating of their host sediments, often enables age-estimates for those layers that do not preserve sufficient or appropriate datable minerals or glass to be obtained (Lowe and Alloway, 2015). Such dating includes most commonly radiocarbon dating of organic materials, together with luminescence dating or palaeomagnetic correlations of inorganic units. Extremely precise ages can also be established in varved sediments or annual layers of ice (e.g. 
Abbott and Davies, 2012; Staff et al., 2013; Lane et al., 2015), as well as by dendrochronology when material is buried by tephra falls or flows (e.g. Hogg et al., 2012; Friedrich et al., 2014). Any age estimate for a tephra can in turn be transferred to all sequences that contain the same horizon - the raison d'être of tephrochronology (sensu stricto). Both traditional and Bayesian age-modelling tools now place tephra connections as a key means to enhance regional palaeoenvironmental, volcanological, and archaeological chronologies by combining age-information across far-reaching tephrostratigraphic frameworks or "lattices" (e.g. Blockley et al., 2008; Smith et al., 2013; Bronk Ramsey et al., 2015; Lowe et al., 2015; Schmid et al., 2017).

Extensive reviews of the theory and applications of tephrochronology and tephrostratigraphy have been published in the last few years, which record and reflect the huge growth in tephra research over several decades (e.g. Lowe, 2011; Lowe et al., 2015) (Fig. 1A). The breadth of applications, both across disciplines and geographical regions, has been markedly increased since the development of methods for detecting and analysing cryptotephra (e.g. Turney et al., 1997; Blockley et al., 2005) (Fig. 1B). Derived from the Greek word kryptein, meaning 'to hide', cryptotephra deposits usually comprise fine-ash-sized glass shards preserved in sedimentary sequences (including ice), or in soils/paleosols, that are insufficiently concentrated to be visible as a layer to the naked eye (Lowe and Hunt, 2001; Davies, 2015; Ponomareva et al., 2015). In some cases, cryptotephras are manifested as crystal (mineral) concentrations rather than, or in addition to, sparse glass shard concentrations (e.g. Hogg and McCraw, 1983; Lowe, 2011; Matsu'ura et al., 2011, 2012, 2014).

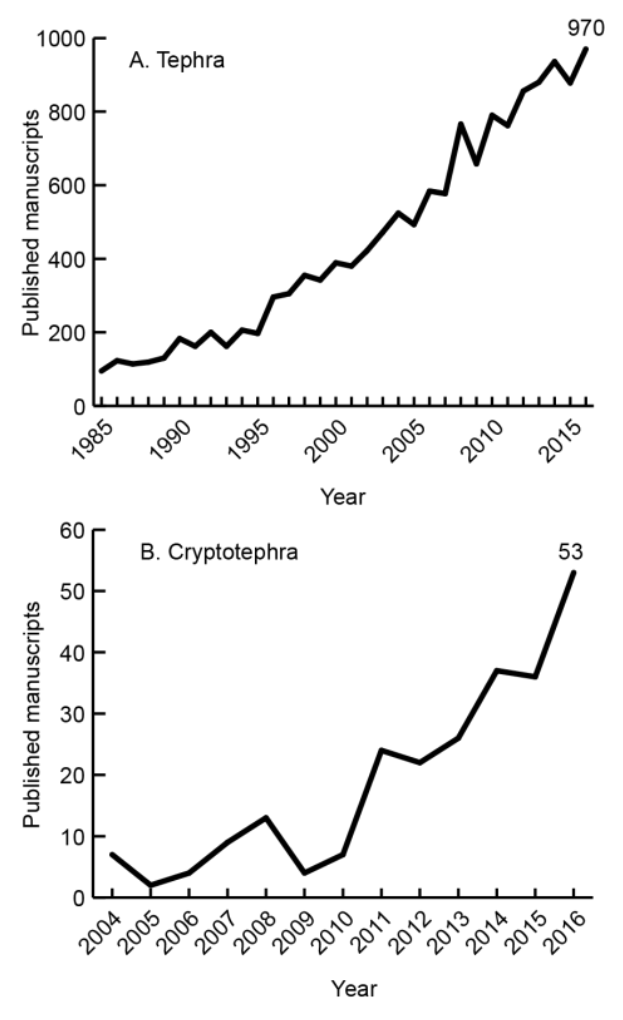

Fig. 1. Numbers of papers involving the terms (A) tephra, as published from 1985 to 2015 , and (B) cryptotephra, as published from 2004 to 2015. In both cases, the numbers relate to searches of Scopus using 'tephra' or 'cryptotephra' in "all fields" (i.e. including title, keywords, and abstracts). Peak numbers are indicated for each dataset. 
Although the key role of visible tephra layers in constructing chronostratigraphic frameworks for type palaeoenvironmental successions is now well established globally (e.g. Blockley et al. 2012; Davies et al., 2012; Lowe et al., 2013; Moriwaki et al., 2016), cryptotephra studies have greatly extended the use of tephrochronology in building age models for palaeoenvironmental sequences in Europe and the North Atlantic regions, where they are identified as a critical tool in the correlation of ice core, marine, and terrestrial archives by the INTIMATE network (INTegration of Ice core, MArine and TErrestrial records, http://intimate.nbi.ku.dk/; Blockley et al., 2014; Davies et al., 2014; Lowe et al., 2015). Cryptotephra research is now being carried out across all continents (Fig. 2), and indeed oceans, as exemplified by some of the papers in this volume (e.g. Martin-Jones et al., 2017; Matsu'ura et al., 2017; Smith et al., 2017; Sun et al., 2017). One very significant finding resulting from the rise in cryptotephra research is the tracing of tephra deposits that have been dispersed across continental distances (Fig. 2). These occurrences vastly extend the use of these deposits as tephrostratigraphic markers because important palaeoclimatic archives can be aligned with certainty at the time of tephra deposition (e.g. Lane et al., 2013; Jensen et al., 2014; Pyne-O'Donnell et al., 2016; van der Bilt, 2017). It has now been shown that glass shards chemically correlated with known (well-characterised) tephra layers from Japan, North America, and Iceland can all be found in the Greenland ice-core records (Bourne et al., 2016). In Antarctic ice cores, tephra layers have been found mainly from eruptions of Antarctic volcanoes, although some glass shards have been tentatively correlated to volcanoes in South America and the South Atlantic (Kurbatov et al., 2006; Narcisi et al., 2010, 2012). The degree of connectivity starting to be observed in the Northern Hemisphere (Fig. 2), where cryptotephra research is commonplace, will inevitably increase, and with further studies, tropical and Southern Hemisphere records will surely also begin to join up. The potential for a unified global tephrostratigraphy, however, is likely still a long way off, as there remain many areas, even in proximal volcanic zones, where detailed tephrostratigraphies for the recent past are still in early development or refinement (e.g. Fontijn et al., 2014; Watson et al., 2015; Damaschke et al., 2017; Johannsson et al., 2017).

Distal tephra applications now extend additionally into archaeology (Riede and Thastrup, 2013; Lane et al., 2014; Alloway et al., 2017; Schmid et al., 2017), volcanology (Shane et al., 2013; Rawson et al., 2016; Smith et al., 2016), and geohazard research (Swindles et al., 2011; Magill et al., 2015; Bourne et al., 2016), where detailed eruption histories are filling the gaps in our knowledge of the frequencies and controls on Quaternary volcanism in less-studied areas (e.g. Martin-Jones et al., 2017). Studies bringing together proximal and distal (often crypto-) tephra datasets to increase our breadth of understanding and generate robust datasets for correlation, are essential to the advance of tephrochronology as a global dating tool. We believe that the diversity of papers in this issue is a good reflection of the work ongoing towards this goal by members of the INTAV community. 


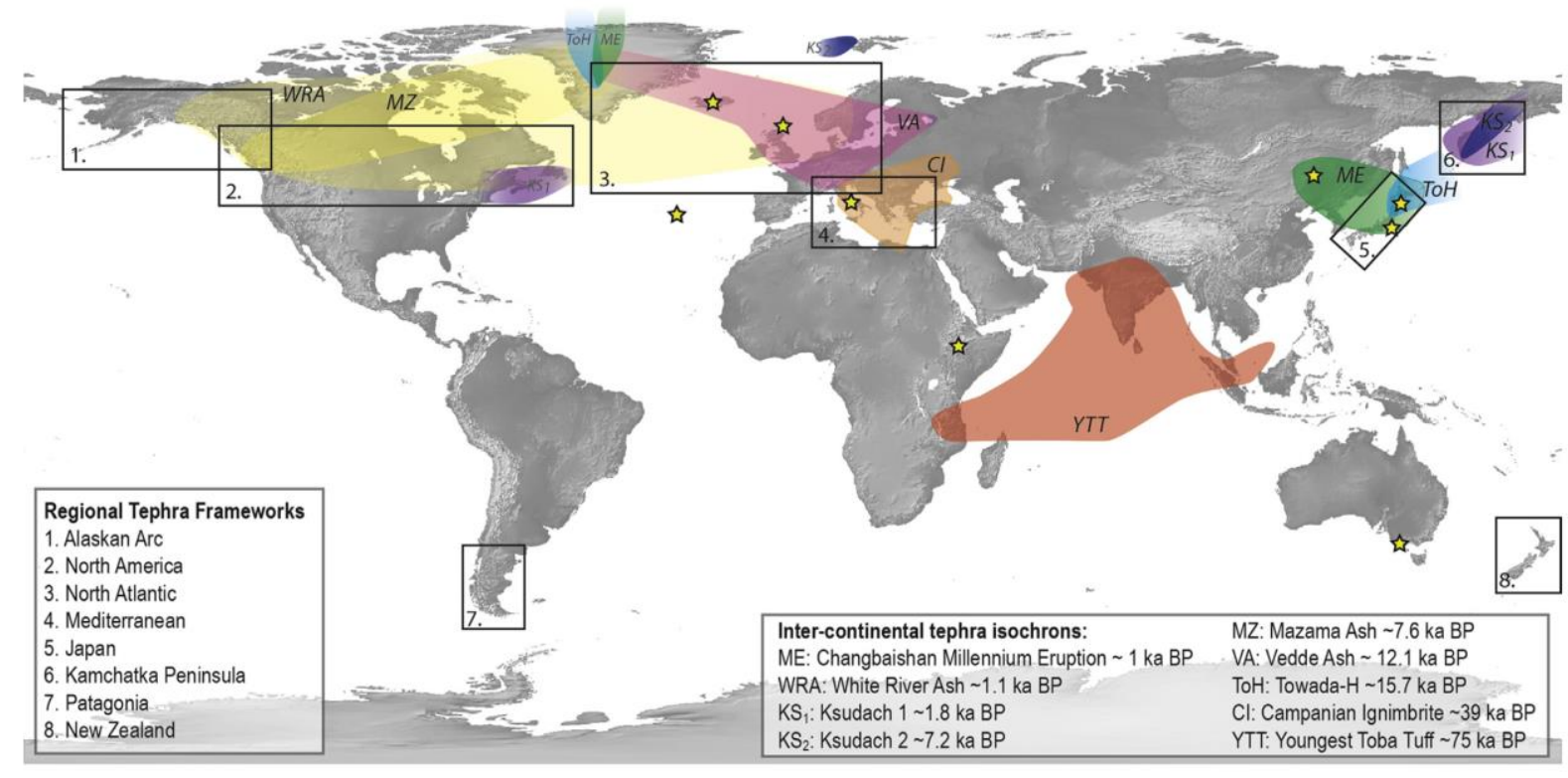

Fig. 2. Global tephra research areas and locations of studies within this volume (stars). Coloured envelopes enclose areas where tephra deposits have been found and geochemically correlated across more than one continent (compiled from references within: Sun et al., 2014; McLean et al., 2016 (ME); Jensen et al., 2014 (WRA); Mackay et al., 2016 (KS1); Kyle et al., 2011, van der Bilt et al., 2017 (KS2); Zdanowicz et al., 1999 (MZ); Lane et al., 2012 (VA); Bourne et al., 2016 (To-H); Tomlinson et al., 2012 (Cl); Lane et al., 2013, Pearce et al., 2014b, Song et al., 2000 (YTT)). Boxes indicate established regional tephrostratigraphic records, where tephra isochrons are widely used for palaeoenvironmental, archaeological, and volcanological research. Key example studies for each numbered region include: 1. Davies et al. (2016); 2. Pyne O’Donnell et al. (2012); 3. Blockley et al. (2014); 4. Lowe et al. (2015); 5. Machida (1999); 6. Kyle et al. (2011); 7. Fontijn et al. (2014); 8. Lowe et al. (2008). Grey Earth basemap from NaturalEarthData.com.

\section{Research goals of the International Focus Group on Tephrochronology and Volcanism}

This special issue, in part, is derived from work supported and promoted by the International Focus Group on Tephrochronology and Volcanism (INTAV). The important and far-reaching role of tephrochronology as a Quaternary correlational and dating method is recognised by the Stratigraphy and Chronology Commission (SACCOM) of the International Union for Quaternary Research (INQUA), which has supported INTAV as an International Focus Group since 2007. During the last 10 years, INTAV has provided a format for collaboration and open discussion between tephrochronologists from around the world, who undertake research across a wide range of disciplines including volcanology, archaeology, palaeoclimatology, and geohazard studies (e.g. Swindles et al., 2011; Biass et al., 2014). INTAV has led numerous tephra conferences between the 4-yearly INQUA congresses, often followed by the publication of tephro-centric proceedings (e.g. Froese et al., 2008; Lowe et al., 2011a). INTAV members have also undertaken specific projects, such as developing inter-laboratory standardisation guidelines (e.g. Kuehn et al., 2011). Consequently, tephrochronology (sensu lato) is 
one of the clearest examples of inter-environmental and inter-discipline working that exists today in the Quaternary and geoscience communities.

Tephra-related focus groups have in fact existed within INQUA since 1961 under various names including the Commission on Tephrochronology (COT) and Subcommission on Tephrochronology and Volcanism (SCOTAV), as summarised in Suzuki et al. (2011). In a community effort to keep on "Advancing Tephrochronology" into the future, INTAV members collaborate within core projects supported by the INQUA commissions as well as those supported by sister organisations including Past Global Changes (PAGES) and the International Association of Volcanology and Chemistry of the Earth's Interior (IAVCEI). A long-term aim is the enhancement of tephrochronology as a global research tool and its application in multiple Quaternary disciplines including geochronology and volcanology. At the same time, INTAV proposes to maintain and extend the capability of the discipline and to promote its value to the wider community, both scientific and general. These aims have been encapsulated by two overarching projects led by INTAV, including the now-completed INTREPID project "Enhancing tephrochronology as a global research tool through improved fingerprinting and correlation techniques and uncertainty modelling" (Lowe et al., 2011b; Lowe, 2015) and, since 2015, the EXTRAS project: "EXTending tephRAS as a global geoscientific research tool stratigraphically, spatially, analytically, and temporally within the Quaternary". EXTRAS is being targeted through seven core objectives (see http://www.comp.tmu.ac.jp/tephra/intavtmu/link.html).

With sadness we record that there have been special colleagues and friends lost to the community over the last few years. At INQUA in Nagoya we marked the passing of Dr Stephen Stokes (19642014, formerly University of Oxford) and Dr Solène Pouget (1987-2015, University of Buffalo), and most recently (July 2016) we heard of the sad loss of Professor Valerie Hall (1946-2016, Queens University Belfast). Valerie was an inspiring friend, colleague, and mentor to many tephra researchers during her career. Valerie's contributions to the discipline, and those of Stephen and Solène, will not be forgotten, and we are pleased to include an obituary for Valerie in the opening pages of this special issue (Plunkett et al., 2017).

\section{Themes in this issue}

Eleven new research articles report on progress made across the tephrochronological community as part of the EXTRAS project. The issue follows on from two excellent conference sessions held in Nagoya at the nineteenth INQUA Congress, in the boreal summer of 2015:

Session SO4: "Tephras and cryptotephras and their use in studies of natural hazards and archaeology", convened by Takehiko Suzuki and Christine Lane; and

Session SO5: "Studies on tephras and cryptotephras and their use as isochrons in palaeoenvironmental and palaeoclimatic reconstructions", convened by David Lowe and Victoria Smith.

In total, close to 50 papers were presented in these sessions and a number of them led directly to contributions in this special issue. In line with the objectives of the EXTRAS project, the papers address a range of topics, covering methodological developments to novel applications, across the disciplines of palaeoclimatology, archaeology, and volcanology. Reflecting the significant growth of 
distal-tephra and cryptotephra research, in particular within palaeoclimatological studies, we include six papers that demonstrate progress at the far frontiers of this area of the discipline. We have arranged the volume into two themes reflecting advances in methodologies and in building regional tephrostratigraphic frameworks that help to facilitate or enhance volcanological, palaeoclimatological, archaeological research.

\section{Theme 1. Advancing methodologies}

Our first two papers deal with advances in methods for the direct dating of tephra samples, a topic critical not only for the reconstruction of volcanic eruption histories and to underpin estimations of volcanic hazard, but also to provide well-dated isochrons essential for the application of tephrochronology (sensu stricto). Ito et al. (2017) demonstrate the application of laser-ablation, inductively-coupled plasma mass spectrometry (LA-ICP-MS) for conducting in situ zircon U-Pb dating. Their findings highlight some of the inherent challenges of this method, whilst providing precise age estimates for key Early to Middle Pleistocene tephra isochrons found across the Boso Peninsula in Japan. Danišík et al. (2017) also address the challenges of U/Pb and (U-Th)/He dating of zircons in tephra, reviewing the progress made using combined $\mathrm{U}$-Th-disequilibrium/U-Pb and (U-Th)/He approaches in dating zircons as young as $2.5 \mathrm{ka}$ and as old as $1.5 \mathrm{Ma}$. The demonstrated advances in "zircon disequilibrium dating" place the method alongside other more established techniques, such as $\mathrm{K}-\mathrm{Ar}, \mathrm{Ar}-\mathrm{Ar}$ and fission track dating, as a key tool for the direct dating of volcanic and pyroclastic deposits.

Large compositional datasets are central to tephrochronology, with geochemical correlations between proximal and distal tephra layers based upon single-grain major through to trace element analyses of glass and/or mineral phases (Lowe, 2011; Tomlinson et al., 2015). One significant area of debate in recent years has been the most appropriate methods for analyses of geochemical data for correlation purposes. Many researchers generally use combinations of binary scatter plots and spider diagrams to discriminate between data or propose correlations. Others have developed further statistical approaches, such as simple correlation coefficients or multivariate methods using discriminant function analysis, principal component analyses, and kernel density estimates (Begét et al., 1991; Pollard et al., 2006; Pouget et al., 2014; Ramsey et al., 2015). Petrelli et al. (2017) explore a novel machine-learning approach for statistical discrimination between Pleistocene Italian tephra. Machine learning is a term derived from the computing literature that refers to statistical methods such as cluster analysis or discriminant analysis. It has been used quite extensively in the geosciences and wider literature for classifying and correlating compositional data and this paper attempts to develop the technique for the purposes of distal tephra correlations. Interestingly, the authors are able to provide new insights into the tephra record of the early Pleistocene Caio section in central Italy, as well as exploring several issues discussed in recent reviews of statistical analyses of tephra, such as the unit sum problem, as considered by Aitchison (1992) and Pollard et al. (2006). Petrelli et al. provide links to the relevant PYTHON codes to allow other uses to test this developing tool against a range of data sets. This approach may have the potential to become a key tool for future analyses of tephra correlations.

One of the greatest challenges in cryptotephra research is achieving robust compositional characterisation of the most distal cryptotephra deposits, which are typically represented by low concentrations of fine-grained glass shards. Working with invaluable cryptotephra deposits in 
Antarctic ice cores, Iverson et al. (2017) explore a set of methods for the isolation, preparation, SEM imaging, and geochemical analysis of the often tiny, and frequently scarce, glass shards. They demonstrate that there is value gained from using SEM on un-polished shards $<10 \mu \mathrm{m}$ in diameter, to measure accurate, albeit less precise, compositions when WDS-EPMA is no longer achievable. The approaches they outline to mount glass shards using computer hard-disk platters follows on from earlier work by Kuehn and Froese (2010). However, they additionally present a flexible work-flow that is adaptable to both visible and cryptotephra samples and should be of benefit to cryptotephra research within a range of sedimentary environments, not just in ice.

\section{Theme 2. Enhancing regional tephrostratigraphies}

An important part of tephra research is the continuing improvement of regional tephrostratigraphic frameworks, which are critical datasets (shared by publication or within on-line databases) for dating and correlating tephra layers across a range of studies. Such improvements may be made via the addition of new sites with detailed tephra records, by exploration of tephra compositions, through new discoveries of tephra in less-explored regions, or through the compilation and application of a tephrostratigraphic framework relevant to a particular research question. The papers within this section cover all of these aspects and highlight some of the most recent and exciting advances in regional tephrostratigraphies. For example, a new dataset of more than 250 Icelandic Viking-age archaeological sites containing tephra layers has been compiled and analysed by Schmid et al. (2017). Sediment accumulation rates, established from ice-core, lacustrine, and aeolian records, together with written records, are used to constrain the ages of 18 key tephra horizons found across Iceland, and beyond. Central to this chronostratigraphy is the first century AD Landnám tephra layer, which is used to define periods of colonisation in Iceland, anchoring the archaeological record within a secure tephrochronological framework.

Timms et al. (2017) present a Lateglacial to Early Holocene tephrostratigraphic record for Quoyloo Meadow in Orkney, demonstrating the value of the cryptotephra approach to dating terrestrial archives far from volcanic regions. Centred in the North Atlantic region, where systematic cryptotephra research, as we now know it, was pioneered (Dugmore, 1989; Turney et al., 1997; Turney, 1998), the authors are able to build a chronology for their record using precisely-dated Icelandic cryptotephra isochrons, then, in turn, improve the age-estimates for less well-studied tephra deposits. Their careful methodology revealed a number of previously un-reported cryptotephra deposits. It is clear that even in regions with established tephrostratigraphic frameworks (Fig. 2; Blockley et al., 2014), detailed cryptotephra studies continue to add to the eruption record and provide new isochrons for the correlation of palaeoclimatological and archaeological sequences.

New cryptotephra discoveries are also presented by Smith et al. (2017), who have located fartravelled mid-Holocene age tephra-derived glass shards in low concentrations within the sediments of Lake Keilambete in Victoria, Australia. Initial evaluations indicate the presence of both local basaltic cryptotephras, probably derived from South Australia's mid-Holocene-age volcanoes of Mt Gambier and/or Mt Shank, and possibly rhyolitic tephra that may have travelled from much farther afield (i.e. from beyond Australia). This research paves the way for further cryptotephra research in Australia, where only isolated discoveries have been made to date (e.g. Lowe, 2008; Coulter et al., 2009) and no connected tephrostratigraphic framework exists. 
Two further articles also explore the potential for distal tephrochronology within geographical regions, or time-frames, where these methods have not yet been widely applied. Martin-Jones et al. (2017) present the first steps toward a Holocene tephrostratigraphy for the Afar region, Ethiopia, where little is known about the eruption record of currently active volcanoes. There is huge potential in this region for improving the chronologies of palaeoclimate archives and for informing geohazard assessment. Similarly, Sun et al. (2017) define a new tephra isochron in China and report the first glass and mineral compositional data for the little studied Arxan-Chaihe volcanic field.

Johannsson et al. (2017) combines distal tephrostratigraphic techniques with proximal datasets to investigate the Holocene record of Faial and San Migeul islands in the Azores. Using major and minor element analyses, they characterised glass-shard compositions of tephra from the volcanoes of Capelinhos, Fogo, Sete Cidades and Furnas. Their findings reveal the source of previously unprovenanced distal cryptotephra deposits found in Ireland and Morocco, and thus add another volcanic centre source into the tephrostratigraphic framework of Europe and the North Atlantic (Fig. 2).

The final article, by Matsu'ura et al. (2017), addresses much longer, and older, tephrostratigraphies, focussed on a marine sequence in the northwest Pacific Ocean. They present a re-evaluated Middle Pleistocene age model combining tephrostratigraphy and cryptotephrostratigraphy with biostratigraphic datasets. In this study, two cryptotephra deposits were found that are indistinguishable by the major- and trace-element compositions of glass shards. They correlated them to known tephra deposits from Japan on the basis of their stratigraphic positions, demonstrating the significance of stratigraphic relationships for extended sequences in areas that frequently receive fall-out tephra, such as the northwest Pacific Ocean area.

Finally, we would like to highlight that more than half of the papers in this volume are led by early career researchers (ECRs). This representation is testament to the excellent support and opportunities provided by the INQUA-INTAV community to ECRs through attendance and participation in workshops, conferences, and field trips, as well as the opportunities for collaboration within an open and active international network. For further details of INTAV research and activities, and to sign up to join in, the reader is referred to the IFG website (http://www.comp.tmu.ac.jp/tephra/intavtmu/top.html) and entries on INQUA's recentlyestablished ECR blog site (http://inqua.org/blog/2016/07/21/intav/).

\section{Acknowledgements}

The guest editors thank the INQUA Nagoya organising committee for supporting the tephra-themed sessions at the congress in 2015, as well as Youping Hou (Elsevier), Rainer Grün (QG Editor), and Daniel Lovegrove ( $Q G$ Manager), for their encouragement and assistance in compiling this volume. This special issue was a great community effort, and therefore we thank the contributing authors and also the reviewers of the papers, many of whom are acknowledged by name, except where they chose to remain anonymous. Cheryl Ward is thanked for assistance with Fig. 1. INTAV is especially grateful to Brad Pillans and Phil Gibbard who, as successive presidents of the Stratigraphy and Chronology Commission (SACCOM) of INQUA from 2007 through to 2015, strongly supported INTAV and its activities in that period. Similar support is being received from Mauro Coltorti (the current 
president of SACCOM), other commission presidents, and the INQUA Executive 2015-2019. This introductory article, and the other papers in the issue, are outputs of INTAV's EXTRAS project "EXTending tephRAS as a global geoscientific research tool stratigraphically, spatially, analytically, and temporally within the Quaternary".

\section{References}

Abbott, P.M., Davies, S.M., 2012. Volcanism and the Greenland ice-cores: the tephra record. EarthScience Reviews 115, 173-191.

Aitchison, J., 1992. On criteria for measures of compositional difference. Mathematical Geology 24, 365-379.

Alloway, B.V., Andreastuti, S., Setiawan, R., Miksic, J., Hua, Q., 2017. Archaeological implications of a widespread 13th Century tephra marker across the central Indonesian Archipelago. Quaternary Science Reviews 155, 86-99.

Begét, J., Edwards, M., Hopkins, D., Keskinen, M., Kukla, G., 1991. Old Crow tephra found at the Palisades of the Yukon, Alaska. Quaternary Research 35, 291-297.

Biass, S., Scaini, C., Bonadonna, C., Folch, A., Smith, K., Höskuldsson, A., 2014. A multi-scale risk assessment for tephra fallout and airborne concentration from multiple Icelandic volcanoes - Part 1 : hazard assessment. Natural Hazards and Earth System Sciences 14, 2265-2287.

van der Bilt, W.G.M., Lane, C.S., Bakke, J., 2017. Ultra-distal Kamchatkan ash on Arctic Svalbard: towards hemispheric cryptotephra correlation. Quaternary Science Reviews 64, 230-235.

Blegen, N., Tryon, C.A., Faith, J.T., Peppe, D.J., Beverly, E.J., Li, B., Jacobs, Z., 2015. Distal tephras of the eastern Lake Victoria basin, equatorial East Africa: correlations, chronology and a context for early modern humans. Quaternary Science Reviews 122, 89-111.

Blockley, S., Pyne-O'Donnell, S., Lowe, J., Matthews, I., Stone, A., Pollard, A., Turney, C., Molyneux, E., 2005. A new and less destructive laboratory procedure for the physical separation of distal glass tephra shards from sediments. Quaternary Science Reviews 24, 1952-1960.

Blockley, S., Ramsey, C.B., Higham, T., 2008. The Middle to Upper Paleolithic transition: dating, stratigraphy, and isochronous markers. Journal of Human Evolution 55, 764-771.

Blockley, S.P.E., Lane, C.S., Hardiman, M., Rasmussen, S.O., Seierstad, I.K., Steffensen, J.P., Svensson, A., Lotter, A.F., Turney, C.S.M., Ramsey, C.B., INTIMATE members, 2012. Synchronisation of palaeoenvironmental records over the last 60,000 years, and an extended INTIMATE event stratigraphy to 48,000 b2k. Quaternary Science Reviews 36, 2-10.

Blockley, S.P., Bourne, A.J., Brauer, A., Davies, S.M., Hardiman, M., Harding, P.R., Lane, C.S., MacLeod, A., Matthews, I.P., Pyne-O'Donnell, S.D., 2014. Tephrochronology and the extended INTIMATE (integration of ice-core, marine and terrestrial records) event stratigraphy 8-128 ka b2k. Quaternary Science Reviews 106, 88-100. 
Bourne, A., Abbott, P., Albert, P., Cook, E., Pearce, N., Ponomareva, V., Svensson, A., Davies, S., 2016. Underestimated risks of recurrent long-range ash dispersal from northern Pacific Arc volcanoes. Scientific Reports 6, 29837.

Coulter, S.E., Turney, C.S., Kershaw, P., Rule, S., 2009. The characterization and significance of a MIS 5a distal tephra on mainland Australia. Quaternary Science Reviews 28, 1825-1830.

Damaschke, M., Cronin, S.J., Holt, K.A., Bebbington, M.S., Hogg, A.G., 2016. A 30,000 yr highprecision eruption history for the andesitic Mt Taranaki, North Island, New Zealand. Quaternary Research 87, 1-23.

Danišík, M., Shane, P.A.R., Schmitt, A.K., Hogg, A.G., Santos, G.M., Storm, S., Evans, N.J., Fifield, L.K., Lindsay, J.M., 2012. Re-anchoring the late Pleistocene tephrochronology of New Zealand based on concordant radiocarbon ages and combined ${ }^{238} \mathrm{U} /{ }^{230} \mathrm{Th}$ disequilibrium and (U-Th)/He zircon ages. Earth and Planetary Science Letters 349-350, 240-250.

Danišík, M., Schmitt, A.K., Stockli, D.F., Lovera, O.M., Dunkl, I., Evans, N.J., 2017. Application of combined U-Th-disequilibrium/U-Pb and (U-Th)/He zircon dating to tephrochronology. Quaternary Geochronology 40, 23-32.

D’Antonio, M., Mariconte, R., Arienzo, I., Mazzeo, F.C., Carandente, A., Perugini, Petrelli, D., Corselli, G., Orsi, M.G., Principato, M.S., Civetta, L., 2016. Combined Sr-Nd isotopic and geochemical fingerprinting as a tool for identifying tephra layers: application to deep-sea cores from eastern Mediterranean Sea. Chemical Geology 443, 121-136.

Davies, S.M., 2015. Cryptotephras: the revolution in correlation and precision dating. Journal of Quaternary Science 30, 114-130.

Davies, S.M., Abbott, P.M., Pearce, N.J.G., Wastegård, S., Blockley, S.P.E., 2012. Integrating the INTIMATE records using tephrochronology: rising to the challenge. Quaternary Science Reviews 36, $11-27$.

Davies, S.M., Abbott, P.M., Meara, R.H., Pearce, N.J.G., Austin, W.E.N., Chapman, M.R., Svensson, A., Bigler, M., Rasmussen, T.L., Rasmussen, S.O., Farmer, E.J., 2014. A North Atlantic tephrostratigraphical framework for 130-60 ka b2k: new tephra discoveries, marine-based correlations, and future challenges. Quaternary Science Reviews 106, 101-121.

Davies, L.J., Jensen, B.J.L., Froese, D.G., Wallace, K.L., 2016. Late Pleistocene and Holocene tephrostratigraphy of interior Alaska and Yukon: kKey beds and chronologies over the past 30,000 years. Quaternary Science Reviews 146, 28-53.

Deino, A.L., 2012. ${ }^{40} \mathrm{Ar} /{ }^{39} \mathrm{Ar}$ dating of Bed I, Olduvai Gorge, Tanzania, and the chronology of early Pleistocene climate change. Journal of Human Evolution 63, 251-273.

Dugmore, A., 1989. Icelandic volcanic ash in Scotland. The Scottish Geographical Magazine 105, 168172. 
Fontijn, K., Lachowycz, S.M., Rawson, H., Pyle, D.M., Mather, T.A., Naranjo, J.A., Moreno-Roa, H., 2014. Late Quaternary tephrostratigraphy of southern Chile and Argentina. Quaternary Science Reviews 89, 70-84.

Friedrich, W.L., Kromer, B., Friedrich, M., Heinemeier, J., Pfeiffer, T., Talamo, S., 2014. The olive branch chronology stands irrespective of tree-ring counting. Antiquity 88, 274-277.

Froese, D.G., Slate, J., Lowe, D.J., Knott, J.R. (Eds), 2008. Global tephra studies: John Westgate and Andrei Sarna-Wojcicki commemorative volume. Quaternary International 178, 1-319.

Griggs, A.J., Davies, S.M., Abbott, P.M., Rasmussen, T.L., Palmer, A.P., 2014. Optimising the use of marine tephrochronology in the North Atlantic: a detailed investigation of the Faroe Marine Ash Zones II, III and IV. Quaternary Science Reviews 106, 122-139.

Griggs, A.J., Davies, S.M., Abbott, P.M., Coleman, M., Palmer, A.P., Rasmussen, T.L., Johnston, R., 2015. Visualizing tephra deposits and sedimentary processes in the marine environment: The potential of X-ray microtomography. Geochemistry, Geophysics, Geosystems 16, 4329-4343.

Hall, M., Hayward, C., 2014. Preparation of micro-and crypto-tephras for quantitative microbeam analysis. Geological Society, London, Special Publications 398, 21-28.

Hogg, A.G., McCraw, J.D., 1983. Late Quaternary tephras of Coromandel Peninsula, North Island, New Zealand: a mixed peralkaline and calkalkaline tephra sequence. New Zealand Journal of Geology and Geophysics 26, 163-187.

Hogg, A.G., Lowe, D.J., Palmer, J., Boswijk, G., Bronk Ramsey, C., 2012. Revised calendar date for the Taupo eruption derived by ${ }^{14} \mathrm{C}$ wiggle-matching using a New Zealand kauri ${ }^{14} \mathrm{C}$ calibration data set. The Holocene 22, 439-449.

Hopkins, J.L., Millet, M.-A., Timm, C., Wilson, C.J., Leonard, G.S., Palin, J.M., Neil, H., 2015. Tools and techniques for developing tephra stratigraphies in lake cores: a case study from the basaltic Auckland Volcanic Field, New Zealand. Quaternary Science Reviews 123, 58-75.

Howe, T., Schmitt, A., Lindsay, J., Shane, P., Stockli, D., 2015. Time scales of intra-oceanic arc magmatism from combined U-Th and (U-Th)/He zircon geochronology of Dominica, Lesser Antilles. Geochemistry, Geophysics, Geosystems 16, 347-365.

Ito, H., Nanayama, F., Nakazato, H., 2017. Zircon U-Pb dating using LA-ICP-MS: Quaternary tephras in Boso Peninsula, Japan. Quaternary Geochronology 40, 12-22.

Iverson, N.A., Kalteyer, D., Dunbar, N.W., Kurbatov, A., Yates, M., 2017. Advancements and best practices for analysis and correlation of tephra and cryptotephra in ice. Quaternary Geochronology 40, 45-55.

Jensen, B.J.L., Pyne-O'Donnell, S., Plunkett, G., Froese, D.G., Hughes, P.D.M., Sigl, M., McConnell, J.R., Amesbury, M.J., Blackwell, P.G., van den Bogaard, C., Buck, C.E., Charman, D.J., Clague, J.J., Hall, V.A., Koch, J., Mackay, H., Mallon, G., McColl, L., Pilcher, J.R., 2014. Transatlantic distribution of the Alaskan White River Ash. Geology 42, 875-878. 
Johansson, H., Lind, E.M., Wastegård, S., 2017. Compositions of glass in proximal tephras from eruptions in the Azores archipelago and their links with distal sites in Ireland. Quaternary Geochronology 40, 120-128.

Kuehn, S.C., Froese, D.G., 2010. Tephra from ice-a simple method to routinely mount, polish, and quantitatively analyze sparse fine particles. Microscopy and Microanalysis 16, 218-225.

Kuehn, S., Froese, D., Shane, P., Participants, I.I., 2011. The INTAV intercomparison of electron-beam microanalysis of glass by tephrochronology laboratories: results and recommendations. Quaternary International 246, 19-47.

Kurbatov, A.V., Zielinski, G., Dunbar, N., Mayewski, P.A., Meyerson, E., Sneed, S.B., Taylor, K., 2006. A 12,000 year record of explosive volcanism in the Siple Dome Ice Core, West Antarctica. Journal of Geophysical Research: Atmospheres 111, D12307, doi: 10.1029/2005JD006072.

Kyle, P.R., Ponomareva, V.V., Rourke Schluep, R., 2011. Geochemical characterization of marker tephra layers from major Holocene eruptions, Kamchatka Peninsula, Russia. International Geology Review 53, 1059-1097.

Lane, C.S., Blockley, S.P., Mangerud, J., Smith, V.C., Lohne, Ø.S., Tomlinson, E., Matthews, I.P., Lotter, A., 2012. Was the 12.1 ka Icelandic Vedde Ash one of a kind? Quaternary Science Reviews 33, 87-99.

Lane, C.S., Chorn, B.T., Johnson, T.C., 2013. Ash from the Toba supereruption in Lake Malawi shows no volcanic winter in East Africa at $75 \mathrm{ka}$. Proceedings of the National Academy of Sciences of the United States of America 110, 8025-8029.

Lane, C.S., Cullen, V., White, D., Bramham-Law, C., Smith, V., 2014. Cryptotephra as a dating and correlation tool in archaeology. Journal of Archaeological Science 42, 42-50.

Lane, C.S., Brauer, A., Martín-Puertas, C., Blockley, S.P., Smith, V.C., Tomlinson, E.L., 2015. The Late Quaternary tephrostratigraphy of annually laminated sediments from Meerfelder Maar, Germany. Quaternary Science Reviews 122, 192-206.

Lind, E.M., Lilja, C., Wastegård, S., Pearce, N.J., 2016. Revisiting the Borrobol Tephra. Boreas 45, 629643.

Lowe, D.J., 2008. Globalization of tephrochronology: new views from Australasia. Progress in Physical Geography 32, 311.

Lowe, D.J., 2011. Tephrochronology and its application: a review. Quaternary Geochronology 6, 107153.

Lowe, D.J., 2015. IFG on tephrochrononology and volcanism (INTAV) project "Enhancing tephrochronology as a global research tool through improved fingerprinting and correlation techniques and uncertainty modelling (phase II)" (INTREPID Tephra-II, INQUA-1307s): final report. Quaternary Perspectives 22 (2), 12-15.

Lowe, D.J., Hunt, J.B., 2001. A summary of terminology used in tephra-related studies. Les Dossiers de l'Archaéo-Logis 1, 17-22. 
Lowe, D.J., Alloway, B.V., 2015. Tephrochronology, in: Rink, W.J., Thompson, J.W. (Eds.), Encyclopedia of Scientific Dating Methods. Springer, Dordrecht, pp. 783-799.

Lowe, D.J., Shane, P.A., Alloway, B.V., Newnham, R.M., 2008. Fingerprints and age models for widespread New Zealand tephra marker beds erupted since 30,000 years ago: a framework for NZINTIMATE. Quaternary Science Reviews 27, 95-126.

Lowe, D.J., Davies, S.M., Moriwaki, H., Pearce, N.J., Suzuki, T. (Eds), 2011a. Enhancing tephrochronology and its application (INTREPID project): Hiroshi Machida commemorative volume. Quaternary International 246, 1-395.

Lowe, D.J., Davies, S.M., Moriwaki, H., Pearce, N.J., Suzuki, T., 2011b. [Preface] Enhancing tephrochronology and its application (INTREPID project): Hiroshi Machida commemorative volume. Quaternary International 246, 1-5.

Lowe, D.J., Blaauw, M., Hogg, A.G., Newnham, R.M., 2013. Ages of 24 widespread tephras erupted since 30,000 years ago in New Zealand, with re-evaluation of the timing and palaeoclimatic implications of the Lateglacial cool episode recorded at Kaipo bog. Quaternary Science Reviews 74, 170-194.

Lowe, J.J., Ramsey, C.B., Housley, R.A., Lane, C.S., Tomlinson, E.L., RESET Team, RESET Associates, 2015. The RESET project: constructing a European tephra lattice for refined synchronisation of environmental and archaeological events during the last c. 100 ka. Quaternary Science Reviews 118, 1-17.

Machida, H., 1999. The stratigraphy, chronology and distribution of distal marker-tephras in and around Japan. Global and Planetary Change 21, 71-94.

Mackay, H., Hughes, P.D.M., Jensen, B.J.L., Langdon, P.G., Pyne-O'Donnell, S.D.F., Plunkett, G., Froese, D.G., Coulter, S., Gardner, J.E., 2016. A mid to late Holocene cryptotephra framework from eastern North America. Quaternary Science Reviews 132, 101-113.

Magill, C., Mannen, K., Connor, L., Bonadonna, C., Connor, C., 2015. Simulating a multi-phase tephra fall event: inversion modelling for the 1707 Hoei eruption of Mount Fuji, Japan. Bulletin of Volcanology 77, 1-18.

Marcaida, M., Mangan, M.T., Vazquez, J.A., Bursik, M., Lidzbarski, M.I., 2014. Geochemical fingerprinting of Wilson Creek formation tephra layers (Mono Basin, California) using titanomagnetite compositions. Journal of Volcanology and Geothermal Research 273, 1-14.

Martin-Jones, C., Lane, C., Pearce, N., Smith, V., Lamb, H., Oppenheimer, C., Asrat, A., Schaebitz, F., 2017. Glass compositions and tempo of post-17 ka eruptions from the Afar Triangle recorded in sediments from lakes Ashenge and Hayk, Ethiopia. Reprinted from Quaternary Geochronology 37, $15-31$.

Matsu'ura, T., Miyagi, I., Furusawa, A., 2011. Late Quaternary cryptotephra detection and correlation in loess in northeastern Japan using cummingtonite geochemistry. Quaternary Research 75, 624-635. 
Matsu'ura, T., Furusawa, A., Yanagida, M., 2012. Detection and correlation of widespread cryptotephras in middle Pleistocene loess in NE Japan using cummingtonite geochemistry. Journal of Asian Earth Sciences 60, 49-67.

Matsu'ura, T., Furusawa, A., Shimogama, K., Goto, N., Komatsubara, J., 2014. Late Quaternary tephrostratigraphy and cryptotephrostratigraphy of deep-sea sequences (Chikyu C9001C cores) as tools for marine terrace chronology in NE Japan. Quaternary Geochronology 23, 63-79.

Matsu'ura, T., Kimura, J.-I., Chang, Q., Komatsubara, J., 2017. Using tephrostratigraphy and cryptotephrostratigraphy to re-evaluate and improve the Middle Pleistocene age model for marine sequences in northeast Japan (Chikyu C9001C). Quaternary Geochronology 40, 129-145.

McLean, D., Albert, P.G., Nakagawa, T., Staff, R.A., Suzuki, T., Smith, V.C., 2016. Identification of the Changbaishan 'Millennium' (B-Tm) eruption deposit in the Lake Suigetsu (SG06) sedimentary archive, Japan: synchronisation of hemispheric-wide palaeoclimate archives. Quaternary Science Reviews 150, 301-307.

Morgan, L.E., 2017. ${ }^{40} \mathrm{Ar} /{ }^{39} \mathrm{Ar}$ and K-Ar geochronology, in: Gilbert, A.S. (Ed.), Encyclopedia of Geoarchaeology. Springer Netherlands, Dordrecht, pp. 27-32.

Moriwaki, H., Nakamura, N., Nagasako, T., Lowe, D.J., Sangawa, T., 2016. The role of tephras in developing a high-precision chronostratigraphy for palaeoenvironmental reconstruction and archaeology in southern Kyushu, Japan, since 30,000 cal. BP: an integration. Quaternary International 397, 79-92.

Narcisi, B., Petit, J.R., Delmonte, B., 2010. Extended East Antarctic ice-core tephrostratigraphy. Quaternary Science Reviews 29, 21-27.

Narcisi, B., Petit, J.R., Delmonte, B., Scarchilli, C., Stenni, B., 2012. A 16,000-yr tephra framework for the Antarctic ice sheet: a contribution from the new Talos Dome core. Quaternary Science Reviews 49, 52-63.

Narcisi, B., Petit, J.R., Langone, A., 2017. Last glacial tephra layers in the Talos Dome ice core (peripheral East Antarctic Plateau), with implications for chronostratigraphic correlations and regional volcanic history. Quaternary Science Reviews 165, 111-126.

Pearce, N.J., 2014. Towards a protocol for the trace element analysis of glass from rhyolitic shards in tephra deposits by laser ablation ICP-MS. Journal of Quaternary Science 29, 627-640.

Pearce, N.J., Abbott, P.M., Martin-Jones, C., 2014a. Microbeam methods for the analysis of glass in fine-grained tephra deposits: a SMART perspective on current and future trends. Geological Society, London, Special Publications 398, 29-46.

Pearce, N.J., Westgate, J.A., Gatti, E., Pattan, J.N., Parthiban, G., Achyuthan, H., 2014b. Individual glass shard trace element analyses confirm that all known Toba tephra reported from India is from the c. 75-ka Youngest Toba eruption. Journal of Quaternary Science 29, 729-734.

Petrelli, M., Bizzarri, R., Morgavi, D., Baldanza, A., Perugini, D., 2017. Combining machine learning techniques, microanalyses and large geochemical datasets for tephrochronological studies in 
complex volcanic areas: new age constraints for the Pleistocene magmatism of central Italy. Quaternary Geochronology 40, 33-44.

Plunkett, G., Pilcher, J., Baillie, M., Coyle McClung, L., Jensen, B., 2017. Obituary - Emerita Professor Valerie Anne Hall BSc PhD FSA FHEA (1946-2016). Quaternary Geochronology 40, 8-11.

Pollard, A., Blockley, S., Lane, C., 2006. Some numerical considerations in the geochemical analysis of distal microtephra. Applied Geochemistry 21, 1692-1714.

Ponomareva, V., Portnyagin, M., Davies, S.M., 2015. Tephra without borders: far-reaching clues into past explosive eruptions. Frontiers in Earth Science 3, article 83, doi: org/10.3389/feart.2015.00083.

Pouget, S., Bursik, M., Cortés, J.A., Hayward, C., 2014. Use of principal component analysis for identification of Rockland and Trego Hot Springs tephras in the Hat Creek Graben, northeastern California, USA. Quaternary Research 81, 125-137.

Pyne-O'Donnell, S.D., Hughes, P.D., Froese, D.G., Jensen, B.J., Kuehn, S.C., Mallon, G., Amesbury, M.J., Charman, D.J., Daley, T.J., Loader, N.J., 2012. High-precision ultra-distal Holocene tephrochronology in North America. Quaternary Science Reviews 52, 6-11.

Pyne-O'Donnell, S.D., Cwynar, L.C., Jensen, B.J., Vincent, J.H., Kuehn, S.C., Spear, R., Froese, D.G., 2016. West Coast volcanic ashes provide a new continental-scale Lateglacial isochron. Quaternary Science Reviews 142, 16-25.

Ramsey, C.B., Housley, R.A., Lane, C.S., Smith, V.C., Pollard, A.M., 2015. The RESET tephra database and associated analytical tools. Quaternary Science Reviews 118, 33-47.

Rawson, H., Pyle, D.M., Mather, T.A., Smith, V.C., Fontijn, K., Lachowycz, S.M., Naranjo, J.A., 2016. The magmatic and eruptive response of arc volcanoes to deglaciation: Insights from southern Chile. Geology 44, 251-254.

Riede, F., Thastrup, M.B., 2013. Tephra, tephrochronology and archaeology-a (re-) view from Northern Europe. Heritage Science 1 (15) (http://www.heritagesciencejournal.com/content/1/1/15).

Schmid, M.M.E., Dugmore, A.J., Vésteinsson, O., Newton, A.J., 2017. Tephra isochrons and chronologies of colonisation. Quaternary Geochronology 40, 56-66.

Shane, P., Gehrels, M., Zawalna-Geer, A., Augustinus, P., Lindsay, J., Chaillou, I., 2013. Longevity of a small shield volcano revealed by crypto-tephra studies (Rangitoto volcano, New Zealand): change in eruptive behavior of a basaltic field. Journal of Volcanology and Geothermal Research 257, 174-183.

Smith, R.E., Tyler, J.J., Reeves, J., Blockley, S., Jacobsen, G.E., 2017. First Holocene cryptotephras in mainland Australia reported from sediments at Lake Keilambete, Victoria, Australia. Quaternary Geochronology 40, 82-91

Smith, V.C., Staff, R.A., Blockley, S.P., Ramsey, C.B., Nakagawa, T., Mark, D.F., Takemura, K., Danhara, T., 2013. Identification and correlation of visible tephras in the Lake Suigetsu SG06 sedimentary archive, Japan: chronostratigraphic markers for synchronising of east Asian/west Pacific palaeoclimatic records across the last 150 ka. Quaternary Science Reviews 67, 121-137. 
Smith, V.C., Isaia, R., Engwell, S.L., Albert, P.G., 2016. Tephra dispersal during the Campanian Ignimbrite (Italy) eruption: implications for ultra-distal ash transport during the large calderaforming eruption. Bulletin of Volcanology 78, 1-15.

Song, S.-R., Chen, C.-H., Lee, M.-Y., Yang, T.F., lizuka, Y., Wei, K.-Y., 2000. Newly discovered eastern dispersal of the youngest Toba Tuff. Marine Geology 167, 303-312.

Staff, R.A., Nakagawa, T., Schlolaut, G., Marshall, M.H., Brauer, A., Lamb, H.F., Bronk Ramsey, C., Bryant, C.L., Brock, F., Kitagawa, H., 2013. The multiple chronological techniques applied to the Lake Suigetsu SG06 sediment core, central Japan. Boreas 42, 259-266.

Sun, C., Plunkett, G., Liu, J., Zhao, H., Sigl, M., McConnell, J.R., Pilcher, J.R., Vinther, B., Steffensen, J., Hall, V., 2014. Ash from Changbaishan Millennium eruption recorded in Greenland ice: Implications for determining the eruption's timing and impact. Geophysical Research Letters 41, 694-701.

Sun, C., Liu, Q., Wu, J., Németh, K., Wang, L., Zhao, Y., Chu, G., Liu, J., 2017. The first tephra evidence for a Late Glacial explosive volcanic eruption in the Arxan-Chaihe volcanic field (ACVF), northeast China. Quaternary Geochronology 40, 109-119.

Suzuki, T., Moriwaki, H., Lowe, D.J., 2011. Hiroshi Machida - respected tephrochronologist, teacher, leader. Quaternary International 246, 6-13.

Swindles, G.T., Lawson, I.T., Savov, I.P., Connor, C.B., Plunkett, G., 2011. A 7000 yr perspective on volcanic ash clouds affecting northern Europe. Geology 39, 887-890.

Timms, R.G.O., Matthews, I.P., Palmer, A.P., Candy, I., Abel, L., 2017. A high-resolution tephrostratigraphy from Quoyloo Meadow, Orkney, Scotland: Implications for the tephrostratigraphy of NW Europe during the Last Glacial-Interglacial Transition. Quaternary Geochronology 40, 67-81.

Tomlinson, E.L., Arienzo, I., Civetta, L., Wulf, S., Smith, V.C., Hardiman, M., Lane, C.S., Carandente, A., Orsi, G., Rosi, M., Muller, W., Menzies, M.A., 2012. Geochemistry of the Phlegraean Fields (Italy) proximal sources for major Mediterranean tephras: implications for the dispersal of Plinian and coignimbritic components of explosive eruptions. Geochimica et Cosmochimica Acta 93, 102-128.

Tomlinson, E.L., Smith, V.C., Albert, P.G., Aydar, E., Civetta, L., Cioni, R., Çubukçu, E., Gertisser, R., Isaia, R., Menzies, M.A., 2015. The major and trace element glass compositions of the productive Mediterranean volcanic sources: tools for correlating distal tephra layers in and around Europe. Quaternary Science Reviews 118, 48-66.

Turney, C.S., 1998. Extraction of rhyolitic component of Vedde microtephra from minerogenic lake sediments. Journal of Paleolimnology 19, 199-206.

Turney, C.S., Harkness, D.D., Lowe, J.J., 1997. Rapid Communication: The use of microtephra horizons to correlate Late-glacial lake sediment successions in Scotland. Journal of Quaternary Science 12, 525-531.

Watson, E.J., Swindles, G.T., Savov, I.P., Bacon, K.L., 2015. First discovery of Holocene cryptotephra in Amazonia. Scientific reports 5. 
Westgate, J.A., Naeser, N.D., Alloway, B., 2013. Fission-track dating, in: Elias, S.A., Mock, C. J. (Eds), Encyclopedia of Quaternary Science, $2^{\text {nd }}$ ed. Elsevier, Oxford, pp. 643-662.

Zawalna-Geer, A., Lindsay, J.M., Davies, S., Augustinus, P., Davies, S., 2016. Extracting a primary Holocene crytoptephra record from Pupuke maar sediments, Auckland, New Zealand. Journal of Quaternary Science 31, 442-457.

Zdanowicz, C.M., Zielinski, G.A., Germani, M.S., 1999. Mount Mazama eruption: calendrical age verified and atmospheric impact assessed. Geology 27, 621-624. 